\title{
Prostasome Involvement in the Development and Growth of Prostate Cancer
}

\author{
Adil A. Babiker ${ }^{1,2}$, Gunnar Ronquist ${ }^{2}$, Bo Nilsson $^{1}$ and Kristina Nilsson Ekdahl ${ }^{1,3, *}$ \\ ${ }^{I}$ Department of Radiology, Oncology and Clinical Immunology, Division of Clinical Immunology, The Rudbeck \\ Laboratory C5, Uppsala, Sweden \\ ${ }^{2}$ Department of Medical Sciences, Division of Clinical Chemistry, University Hospital, Sweden \\ ${ }^{3}$ Department of Chemistry and Biomedical Sciences, University of Kalmar, Sweden
}

\begin{abstract}
Prostasomes are extracellularly occurring submicron, membrane-surrounded organelles produced by the epithelial cells of the prostate and present in semen after secretion. Even dedifferentiated prostate cancer cells have preserved their ability to produce and export prostasomes to the extracellular space. The precise physiological role of prostasomes is not known, although some of their properties assign them to important physiological and patho-physiological functions that could be exploited in prostate cancer growth and development. In this review, some new properties of seminal and malignant cell line (DU145, PC-3 and LNCaP) prostasomes will be discussed.

There are typical differences in the expressions and activities of prostasomal CD59, ATPase, protein kinases and tissue factor (TF) as well as in the transfer of prostasomal CD59 to CD59-deficient erythrocytes (rabbit and human PNH erythrocytes). CD59, protein kinases and TF exhibit characteristic patterns of overexpression by malignant cell prostasomes. A high ATPase activity is recognized on seminal prostasomes with minimal activity on malignant cell prostasomes resulting in more residual ATP available for phosphorylation reactions. Several proteins are phosphorylated by prostasomal protein kinases, namely, complement component $\mathrm{C} 3$, fibrinogen, vitronectin and E-cadherin. Furthermore, TF is identified as the main endogenous phosphorylation substrate on prostasomes. In addition, prothrombotic effects of prostasomes are demonstrated. DU145 and PC-3 cell-derived prostasomes exert a higher clotting effect on whole blood and plasma compared to $\mathrm{LNCaP}$ cell-derived and seminal prostasomes.

In conclusion, malignant cell prostasomes show an increased ability to interact with the biological system in favor of prostate cancer cell promotion and survival. The roles played by prostasomes in this context may improve the understanding of the mechanisms that help the prostate cancer cells to avoid the complement attack (CD59 transfer and phosphorylation and inactivation of $\mathrm{C} 3$ ), to promote angiogenesis (TF) and to metastasize. It may also provide a better understanding of some of the complications usually seen in some terminal prostate cancer patients like thrombotic events and tendency to develop disseminated intravascular coagulation.
\end{abstract}

Keywords: ATPase, CD59, CK, complement, DU145, Extracellular phosphorylation, LNCaP, PC-3, PKA, PKC, prostasomes, prostate cancer, protein kinases, tissue factor.

\section{GENERAL BACKGROUND}

\section{A. Prostate Cancer}

Prostate cancer is the most prevalent noncutaneous cancer in many of the Western countries and is the second leading cause of cancer death in men in USA [1]. The introduction of prostate specific antigen (PSA) in the latter half of 1980 s as a biochemical marker of prostate cancer in serum signified a radical change of the pattern of prostate cancer diagnosis. It meant that more cases were detected at an early stage and substantially fewer at advanced stages [2]. The

*Address correspondence to this author at the Department of Radiology, Oncology and Clinical Immunology, Division of Clinical Immunology, The Rudbeck Laboratory C5, University Hospital, SE-751 85 Uppsala, Sweden; Tel: +46 18-611 1171; Fax: +46 18-55 31 49;

E-mail: kristina.nilsson_ekdahl@klinimm.uu.se causes of prostate cancer are essentially unknown. Still, several factors have been connected with a higher risk for this type of cancer. These are increasing age, family history of prostate cancer, and men in Western countries (especially American men of African heritage) [3]. There are also studies showing that increasing incidence of prostate cancer affects men who have migrated from low-risk to high-risk countries $[4,5]$. Androgen stimulation may imply a carcinogenic factor, since testosterone promotes proliferation of prostate epithelial cells and inhibits cell death [6]. It has been reported that prostate cancer is extremely rare in men castrated before reaching puberty [7].

A clear discrepancy exists between the high incidence of cancer in the prostate gland and the conspicuously low incidence of primary cancer in the seminal vesicles [8]. This deserves attention since the two glands represent neighboring anatomical locations, both of them being exocrine acces- 
sory genital glands, and both being under similar hormonal control. The prostate gland, contrary to seminal vesicles, is distinguished by its ability to produce and secrete prostasomes [9]. Not only normal prostate acinar secretory cells but also neoplastic prostate cells have the capacity to synthesize and export prostasomes to the extracellular space $[10$, $11]$.

It is a long-known principle that tumor cells, opportunistically, tend to exploit the host's physiologic systems in order to get support in terms of e.g. nutrition, growth, and metastasis. It has been claimed that several prostasomal abilities, primarily developed for the sustenance of the fertilizing sperm cells, also can be promotive in the transition from a normal to a neoplastic cell and help the prostasomeproducing, poorly differentiated cancer cells to survive as metastases [12]. The control of cell proliferation, differentiation, and signal transduction pathways are generally mediated by protein kinases and phosphatases $[13,14]$ whose actions are modified by hormones, growth factors, and mitogens [15]. As a matter of fact, which will be discussed later in this review $(\mathrm{V}: \mathrm{F})$ an upregulation of protein kinase activities was generally observed in prostasomes derived from prostate cancer cells in comparison with prostasomes of a normal cell origin.

\section{B. The Complement System: Its Function and Activation}

The complement system is an important part of the body's innate immune system. It comprises about 30 distinct plasma and cell bound proteins that react with one another in an orderly way to opsonize pathogens and induce a series of inflammatory responses that help fight infection. Opsonization is the facilitation of phagocytosis of microorganisms or other cells/particles e.g. erythrocytes, through the coating of their surface with opsonins, which are generally proteins secreted as the products of complement activation. The complement activates in the absence or presence of antibodies through triggered-enzyme cascades. The complement system achieves its function through main effector mechanisms, namely, opsonization of pathogens by $\mathrm{C} 3 \mathrm{~b}$ and $\mathrm{C} 4 \mathrm{~b}$, recruitment of inflammatory cells, mediating chemotaxis and release of anaphylatoxins ( $\mathrm{C} 3 \mathrm{a}$ and $\mathrm{C} 5 \mathrm{a}$ ), lysis of certain pathogens and cells by the C5b-9 complex, recognition and clearance of apoptotic cells and handling of immune complexes.

The complement system could be activated through the alternative pathway (APW), the classical pathway (CPW) or the lectin pathway (LPW). All pathways end in the terminal pathway which leads to the formation of the membrane attack complex (MAC or C5b-9) that forms pores in the cell membrane leading to cell lysis and death [16-21]. In some cases sublytic concentrations of membrane attack complex have been shown not to cause cell lysis but rather initiate signals that lead to cell apoptosis [22-24] or stimulate some cell types like the platelets [25].

\section{Regulation of the Complement System}

The activation of complement is under strict control in order to avoid unwanted activation of the complement on host cells. Complement regulators are either soluble proteins e.g. $\mathrm{C} 1$ inhibitor $(\mathrm{C} 1-\mathrm{INH})$ or membrane bound proteins. The membrane bound complement regulatory proteins are complement receptor 1 (CR1, CD35), membrane co-factor protein (MCP, CD46), decay accelerating factor (DAF, CD55) and membrane inhibitor of reactive lysis (MIRL, CD59).

\section{Membrane Inhibitor of Reactive Lysis (CD59)}

CD59, also known as protectin or membrane attack complex inhibitory factor (MACIF), is a regulator of complement activation that is expressed on erythrocytes, leukocytes, epithelial and endothelial cells and prostasomes (see below). CD59 inhibits complement-mediated lysis by preventing full assembly of the membrane attack complex (MAC) on host cells. It binds to $\mathrm{C} 8$ in the $\mathrm{C} 5 \mathrm{~b}-8$ complex, preventing the polymerization of $\mathrm{C} 9$ during the final step of MAC formation $[17,26]$. CD59 attaches to the cell membrane by a glycosylphosphatidylinositol (GPI) anchor and its molecular weight ranges between $18-26 \mathrm{kDa}$ [27]. In a clinical condition known as paroxysmal nocturnal hemoglobinuria $(\mathrm{PNH})$ some clones of erythrocytes may lack CD59 and thus become vulnerable to complement-mediated lysis resulting in intravascular hemolysis. PNH is thus considered an uncommon acquired clonal hematologic stem cell disorder classified as an intravascular hemolytic anemia due to the deficiency of CD59 on PNH erythrocytes [28, 29].

It has been postulated that the protein kinases (PKs) may play a role in complement regulation. Depending on their physiological substrate PKs may be able to inhibit the formation of convertases or MAC thus inhibiting complement activation. Through this mechanism PKs may play a possible role in the development and/or aggravation of some pathological conditions like cancer. Paas and Fishelson [30] have described the presence of tyrosine and serine/threonine ectoprotein kinases on the surface of intact cells, e.g. U937 histocytic leukemia human cell line, and also on microparticles derived from these cells. They also provided evidence that these ecto-protein kinases phosphorylate, among several other proteins, C9 and to some extent C3. In an another work by Ekdahl and Nilsson [31] it has been demonstrated that $\mathrm{C} 3$ synthesized by monoblastoid cell line U937 was phosphorylated by casein kinase II.

\section{Role of Complement in Tumor Surveillance}

It has been suggested that the complement system is involved in the immunosurveillance against tumors [32]. Complement activation on tumors may occur in response to the formation of immune complexes containing anti-tumor antibodies, through spontaneous activation of the APW in response to altered cell surface expression [33] or through tissue destruction resulting from tissue ischemia and necrosis [34]. Various tumors have been shown to use different cooperating and synergistic mechanisms to evade the attack by the complement system, indicating that evasion of complement attack is one of the basic mechanisms in tumor development $[35,36]$. An important mechanism is the overexpression of complement regulatory proteins such as membrane cofactor protein (MCP; CD46), decay accelerating factor (DAF; CD55) and CD59, on the tumor cell surface or in the extracellular environment in e.g. thyroid, prostate, gastric, breast, colon and ovarian cancer [32, 35-43]. Donin et al. [35] have shown through antibody blocking that CD59 produces a more complete inhibition of the complement cascade than does CD46 or CD55. They also demonstrated that 
blocking of CD59 with monoclonal antibody (mAb) sensitizes breast, ovarian and prostate carcinoma cells to complement attack. An interesting observation has been made by Gazouli et al. [44] in that the CD59 gene contains regulatory elements controlled by $\mathrm{p} 53$, suggesting that $\mathrm{p} 53$ up-regulates CD59 on the tumor cell surface.

\section{THE SECRETORY FUNCTION OF THE PROS- TATE GLAND}

\section{A. The Nature of Prostatic Secretion}

The prostate gland produces a protease-rich fluid that constitutes about $30 \%$ of the ejaculate. This secretion is transported to the urethra via prostatic ducts. It is a slightly acidic ( $\mathrm{pH} 6.5)$, serous fluid in which several major secretory products can be identified. It contains high concentrations of prostatic acid phosphatase (PAP) and prostate specific antigen (PSA) (two important markers). It contains also amylase, proteolytic enzymes, fibrinolysin, citric acid, zinc, calcium, magnesium, sodium, potassium, carbohydrates, polyamines, hormones, lipids and growth factors $[45,46]$.

The major prostate specific proteins are PAP and PSA, as mentioned above, which are expressed at pubertal and adult age. Proteolysis is the major function of prostate secretion, being rich in also exopeptidase and endopeptidase. The most extensively studied proteolytic enzyme is PSA. PSA is a member of the human kallikrein family, which in turn is a subgroup of the serine protease family, and PSA is also known as seminin, seminal protease or chymotrypsin-like protease $[47,48]$.

Albumin is present in semen at a higher concentration (0.5-1.4 g/L) than any other plasma protein. The prostate gland is considered to be the major site of albumin transudation [49]. Human seminal plasma contains also coagulation and fibrinolytic proteins mainly of prostatic origin.

\section{B. The Glandular Epithelia}

The prostatic epithelia and stromal compartments act together as one functional unit, and evidence suggests that stromal-epithelial interactions play an important role in regulating prostatic development and growth $[50,51]$. The glandular epithelial tissues are formed by cells specialized in producing fluid secretion that is different from blood plasma and intercellular fluid.

\section{PROSTASOMES}

\section{A. Their Origin and Secretion}

Tall columnar cells with basally orientated nuclei constitute a surface layer of acinar cells in the prostate gland [52]. These secretory cells of the mature prostate contain highly organized organelles named prostasomes [9], which are released into the prostatic fluid and semen by exocytosis $[9$, 52]. This observation of membrane-surrounded prostasomes in an extracellular position [53-55] was notable and initially the object of some doubt. The idea of an extracellular occurrence of organellar structures like prostasomes was subsequently corroborated by the demonstration of the extracellular occurrence of exosomes produced by other cell systems [56-59]. Accordingly, exosomes are small membrane vesi- cles that are released into the extracellular environment during fusion of multivesicular bodies (MVB) with plasma membrane. Similarly, prostasomes are formed in the apical part of prostatic luminal epithelial cells. This locus, near the upper pole of the nucleus, is the area where the Golgi apparatus is most abundant $[9,52]$. Prostasome biogenesis presupposes the existence of the so-called "late endosomes" and involves the inward budding of what was originally called "storage vesicles" [9] that should be understood as equivalent to the aforementioned MVB being capable of fusion with the plasma membrane and release of prostasomes by exocytosis $[9,52]$. The phospholipid composition of prostasomes reveals some extraordinary peculiarities. Sphingomyelin is the predominant phospholipid class representing almost half of the total phospholipid measured [60, 61]. Sphingomyelin phosphodiesterase has been described in prostasomes [62] and this enzyme might be directly involved in the inward budding of the membrane of MVB (or storage vesicle) and thus formation of prostasomes ("secondary vesicles"). Sphingomyelin phosphodiesterase cleaves off the ceramide portion of sphingomyelin releasing phosphocholine. The ceramide moiety has been implicated in the formation of exosome vesicles in MVB [63]. This inward budding is preferentially taking place in raft-associated microdomains of the membrane [64]. PC-3 cells have been established as an epithelial cell line from a human prostatic adenocarcinoma metastatic to bone [65] and these cells have been used as model cells to acquire insights in the production and release of prostasomes. Delta-catenin was identified in culture media of PC-3 cells, which was partially co-localized and co-isolated with raft-associated membrane protein caveolin-1 and CD59, suggesting its potential excretion into extracellular milieu through exosome/prostasome associated pathways [66]. Similarly, Llorente et al. [67] observed a high level of co-localization of caveolin-1 and raft-associated integral membrane proteins of the MAL family in an intracellular multivesicular compartment (MVB or storage vesicles). The same set up of proteins was again found in the prostasome fraction released from PC-3 cells into the culture medium [67] giving strong support to the idea that prostasomes originate as secondary vesicles in MVB before their extracellular appearance as a result of exocytosis. A subsequent study by Llorente et al. [68] revealed that cholesterol can regulate the release of prostasomes from the PC-3 cells. This conclusion was reached after observing that PC-3 cells subjected to cholesterol-depleting drugs increased their secretion of prostasomes [68].

\section{B. Types of Prostasomes Used Experimentally}

Prostasomes can be obtained from semen by differential centrifugations including preparative ultracentrifugations followed by gel filtration (seminal prostasomes). Additionally, after homogenization procedures followed by aforementioned line of action for seminal prostasomes, nonmalignant prostatic tissue (native prostasomes), prostate cancer metastasis (metastatic prostasomes) or prostatic cancer cell line namely, DU145 (from brain metastasis), PC-3 (from bone metastasis) and LNCaP (from lymph node metastasis) can be prepared. The authenticity of prostasomes derived from prostatic cancer cell lines prepared in this way was proven by their strictly high cholesterol/phospholipid ratio [69]. 


\section{Prostasomal Membrane Architecture}

The prostasome membrane architecture is unique in its composition as regards the lipid content. Quantitative analysis of membrane lipids revealed domination of cholesterol over phospholipids. The molar ratio of cholesterol/ sphingomyelin/glycerophospholipids was found to be $4: 1: 1$. Thus, the cholesterol/phospholipid ratio, being 2.0 [60], was very high in comparison to most other plasma membranes including that of spermatozoon being 0.83 [70].

\section{Prostasomal Membrane Enzymes}

Prostasomal membrane contains several enzymes, the physiological role of most of them being not yet known. Prostasomes show a rather high ATP-splitting activity, which is linked to their membrane [9]. The $\mathrm{Mg}^{2+}$ and $\mathrm{Ca}^{2+}$ stimulated ATPase enzyme of the prostasomal membrane is calmodulin-dependent [71]. They contain also $\gamma$-glutamyltransferase whose activity in seminal plasma is more than 1000 -fold higher than in normal serum [72]. The prostate is the major source of this enzyme [73] and the most of it is bound to the membrane of the prostasomes [74]. Prostasomes also possess arachidonate 15-lipoxygenase activity [75] which catalyses oxygenation at the n-6 carbon of many polyunsaturated fatty acids, leading to the formation of a cistrans conjugated hydroperoxy fatty acid, which is reduced, enzymatically or non-enzymatically, to a conjugated hydroxy fatty acid. Arachidonate 15-lipoxygenase seems to be important in the acrosome reaction of bull spermatozoa [76]. Neutral endopeptidase (NEP) is a $100 \mathrm{kDa}$ prostasomeassociated highly glycosylated membrane-bound enzyme [77].

Prostasomes contain the membrane-bound 5'-nucleotidase enzyme (5-ribonucleotide phosphohydrolase) [78]. It is a phosphohydrolase that specifically catalyses the hydrolysis of 5 -nucleotides and is widely distributed in animal and human tissues including bull and human semen. Its activity is increased in the presence of $\mathrm{Mg}^{2+}$ or $\mathrm{Mn}^{2+}$ and strongly inhibited by $\mathrm{Ni}^{2+}$. No definite physiological role has been identified.

Dipeptidyl peptidase IV (CD26) activity was found to be extremely high in prostasomes [79]. CD26 is a surface antigen that has been found in several cell types. It is a type II integral membrane protein [80] and possesses a peptidase activity. It is a highly specific serine-type protease that cleaves $\mathrm{N}$-terminal dipeptidase from peptides with a proline or alanine at the penultimate position [81]. Dipeptidyl peptidase IV was transferred to spermatozoa upon incubation with prostasomes. Many biologically active peptides are substrates for dipeptidyl peptidase IV [82] but its exact physiological role in humans is not yet fully known. Aminopeptidase $N(C D 13)$ is a $150 \mathrm{kDa}$ zinc-dependent proteolytic enzyme usually used as a marker for prostasomes [72, 83].

Prostasomal protein kinase activity:

Stegmayr et al. (1982) first demonstrated the presence of protein kinase activities in the secretory granule and vesicle prostasome fraction of seminal plasma [84]. Spermatozoa contain protein kinase A (PKA) that may modulate sperm function [85-88]. It was suggested that, in vivo about half the protein kinase in seminal plasma was bound to prostasomes [89].

\section{E. Functional Role of Prostasomes}

Despite that many cell physiological and biochemical expressions of prostasomes have shown in vitro, yet their physiological role is not fully known, but the results of some works could assign them to some important functions.

\section{Sperm-Prostasomes Interaction}

Prostasomes can adhere to and, to some extent, fuse with human spermatozoa as shown by free zone electrophoresis and electron microscopy [90], octadecyl-rhodamine fluorescence self-quenching [91] and immunofluorescence staining and confocal microscopy [92]. The fusion was shown to be cation-independent, strictly dependent on $\mathrm{pH}$ and quite a sperm- specific phenomenon. Membrane fusion may represent an important physiological mechanism to help spermatozoa resist the vaginal acidic milieu. Another result of this fusion could be the transfer of certain prostasomal enzymes to the spermatozoa, i.e. aminopeptidase N (CD13) [93] and dipeptidylpeptidase IV (CD26) [94].

Prostasomes were found to promote the sperm forward motility [95-97]. Prostasomes also increased the number of hyperactivated spermatozoa [96], which is thought to be an important parameter for the penetration of the zona pellucida and subsequently for the fertilization [98].

\section{Anti-Bacterial and Anti-Viral Effect of Prostasomes}

Prostasomes have a bactericidal effect [99]. Their antibacterial activity is associated with bacterial membrane deformation. Thus the bactericidal mechanism of prostasomes may be due to the effect of prostasomal proteolytic enzymes, making it mechanistically different from that of neutrophil granulocytes, which are dependent on the generation of reactive oxygen species (ROS) for their killing of invading microorganisms.

It has been demonstrated that prostasomes could inhibit viral activity, probably via their membrane cofactor protein (MCP; CD46) [100]. Kitamura et al. attributed this activity to the effect that prostasomes functioned like mock cells, and by taking up the virus, rendered it unable to infect the cells.

\section{Anti-Oxidant Activity of Prostasomes}

Prostasomes can inhibit superoxide anion production by neutrophils [101]. It seems that an exchange reaction of lipids (especially of sphingomyelin and cholesterol) between prostasomes and neutrophils results in the inhibition of the NADPH oxidase activity of the granulocytes and therewith abolition of the free radical formation [102].

\section{Innate-Immunosuppressive Properties of Prostasomes}

Prostasomes also contain the complement regulatory proteins CD46 (membrane cofactor protein, MCP), CD55 (decay accelerating factor, DAF), both being expressed in very small amounts, and CD59 [103, 104]. The complementregulatory effect of prostasomes [103], is mainly mediated by their content of CD59, which is present in seminal plasma at a concentration of $20-30 \mu \mathrm{g} / \mathrm{mL}$ [104]. It was possible to transfer GPI-anchored proteins of prostasomes such as CD59 to spermatozoa and guinea pig erythrocytes [104]. Beside their content of complement regulatory proteins, prostasomes are considered roughly immunosuppressive due to their effect on neutrophils $[101,105,106]$. 


\section{Prostasomal Tissue Factor (TF) and Seminal Clotting}

The potent procoagulant activity of seminal plasma added to human blood plasma was first described in 1942 [107]. This potent clotting activity is due to a high concentration of functional tissue factor [108-110]. Human tissue factor (TF, coagulation factor III, CD142) is a $43-45 \mathrm{kDa}$, single chain, transmembrane glycoprotein which serves as an essential cofactor for factor VII in initiating the physiological coagulation cascade of the blood. TF is present in seminal plasma in association with prostasomal membrane at a very high concentration $(21 \mathrm{ng} / \mathrm{mL})$ [108], compared to the concentration of the free soluble domain of $\mathrm{TF}$ in blood which mounts to $85 \mathrm{pg} / \mathrm{mL}$. Most, if not all, of TF activity in seminal plasma is assignable to the prostasomes. TF, beside its role in activation of coagulation of blood, may play a role in controlling the balance of angiogenic and anti-angiogenic factors $[111,112]$. Angiogenesis, angiogenetic proteins and neo-vascularization are important in cancer as well as nonneoplastic conditions as wound healing where TF is usually overexpressed [113]. TF, has also been suggested to play a major role as a morphogenic factor during early embryonic development $[114,115]$. Some researchers speculated about the assignment of seminal $\mathrm{TF}$ for other functions rather than blood coagulation due to its very high expression in semen in comparison to other coagulation proteins [110, 116-118]. Prostasomal TF may protect against anti-sperm antibody development and against transmission of infectious agents [108]. It is the major factor in inducing the formation of the seminal coagulum which may be important for the sperm biology. TF may also participate in preparation of endometrium for implantation of the fertilized ovum and placental development [119].

Increased coagulation is frequently seen in patients with advanced prostate cancer [120]. Multiple studies demonstrated high expression of TF in both primary prostate tumors and in metastases. It is postulated that TF has a role in regulating prostate cancer progress and angiogenesis [121, 122]. TF was found to up-regulate the expression of IL-8 on the surface of breast carcinoma cells by binding to factor VIIa, which led to increased cell migration and invasion [123]. Normally, hemostasis and angiogenesis are tightly regulated processes both being less regulated in cancer. TF is being discussed both as a useful prognostic marker for patients with metastatic prostate cancer [124] as well as a potential target molecule for specific immunotherapy in prostate cancer [125].

Biochemical studies have shown $\mathrm{TF}$ to be palmitylated and phosphorylated via the cytoplasmic domain. These posttranslational modifications are expected to affect its structural and functional properties [126-128].

\section{SEMINAL PROTEIN KINASES AND PROTEIN PHOSPHORYLATION}

Phosphorylation is a very fast way of regulating proteins and modifying their properties e.g. enzymatic or co-factor activity, affinity for ligands or susceptibility for degradation. Phosphorylation is an enzymatic reaction catalyzed by protein kinases. Protein kinases catalyze the transfer of the $\gamma$ phosphoryl group of ATP (or GTP) to an amino acid side chain of a protein substrate in the presence of divalent cations. These enzymes could be subdivided into two main groups based on their ability to transfer the $\gamma$-phosphate of ATP or GTP to $(i)$ alcohol groups on serine/threonine, or (ii) phenolic groups on tyrosine residues of their protein substrates.

The serine/threonine protein kinases can be divided further on the functional basis of being either [13]:

1. Second messenger dependent [e.g. cAMP-dependent protein kinase (PKA), cGMP-dependent protein kinase, diacylglycerol-activated/phopholipid dependent protein kinase $\mathrm{C}(\mathrm{PKC}), \mathrm{Ca}^{2+} /$ calmodulin-regulated protein kinase].

2. Second messenger independent (e.g. casein kinases CKI and CKII).

Protein kinases which have the tyrosine as the target amino acid include the hormone receptor associated kinases (e.g. insulin receptor and epidermal growth factor) and oncogene products (e.g. Src, Ras and Ab1). Protein kinases with dual specificity can phosphorylate tyrosine and serine/ threonine residues [e.g. mitogen-activated protein kinases (MAPKs)]. Protein phosphorylation is implicated in controlling several biochemical events such as metabolism, membrane transport, neurotransmission, genomic activation, transcription and cell proliferation [13, 14, 129]. Protein phosphorylation is reversibly controlled by phosphatases (dephosphorylation).

Protein kinases and phosphatases are secreted among other proteins by the prostate gland. The presence of protein kinases in testis and accessory gland of male reproductive tract and differential sensitivity of theses enzymes has been described before $[85,130]$. The presence in seminal fluid of a cAMP-dependent protein kinase with a high specificity for histone has also been demonstrated [131]. Wilson et al. [132] suggested the presence of more than one protein kinase in the seminal fluid. They also concluded that the presence of phosphoprotein phosphatases in seminal fluid, under the experimental conditions they used, did not influence protein kinase reaction towards anionic and cationic protein substrates. Speculations about the source of protein kinases suggested that they derived from the prostate gland, spermatozoa and to a lesser extent from the seminal vesicles [131, $133,134]$.

The presence of protein kinase activities in the membranes of secretory granules and vesicles of prostatic origin (prostasomes) in human seminal plasma was first demonstrated by Stegmayr et al. [84]. They demonstrated that the protein kinases in these organelles phosphorylated both serine and threonine residues in histones, phosvitin and endogenous prostasomal proteins. Protein kinase activity, mainly belonging to the PKA group of enzymes, is associated with prostasomes $[89,135]$. Prostasomes also show high ATP-cleavage activity which is linked to their membrane [9, $54,55]$. This cleavage activity is due to the $\mathrm{Mg}^{2+}$ and $\mathrm{Ca}^{2+}$ stimulated ATPase enzyme of the prostasomal membrane which is calmodulin-dependent [71].

\section{PROSTASOMES AND PROSTATE CANCER CELL PROTECTION}

\section{A. Pluripotency of Prostasomes}

Prostasomes possess a pluripotency in reproduction by which they ensure the spermatozoa abilities to pass and sur- 
vive in the lower and upper female genital tract, to penetrate the zona pellucida and successfully fertilize the ovum. These potencies of prostasomes are, however, a double-edged sword. It is a long-known principle, as estimated above, that tumor cells tend to exploit the host's physiological systems in order to get support in terms of, for example, nutrition, growth or metastasis. Hence, it was crucial to investigate whether the prostasomal abilities that were favorable for the reproduction process also could be favorable for the prostasome-producing, poorly differentiated neoplastic prostate cells to survive as metastases. Our hypothesis was based on the abundant occurrence of CD59 in the prostasomal membrane and on our initial finding that this membrane-bound CD59 could be released and transferred to CD59-deficient red blood cells, which were thereby rendered resistant to a subsequent complement attack and hemolysis. These unambiguous effects on the otherwise unprotected red blood cells against a complement attack tempted us to further study these phenomena in prostasome-producing prostate cancer cells and their ability to counteract the immune defense. This was also justified by the fact that prostate cancer cells were indeed able not only to synthesize but also to release prostasomes to their close extracellular environment.

\section{B. The Transfer of Prostasomal CD59 to CD59-Deficient Erythrocytes}

A previous work of Rooney et al. [103] showed that spermatozoa and guinea pig erythrocytes could acquire CD59 of seminal plasma and prostasomes. In our published work $[136,137]$ we presented data showing that erythrocytes lacking CD59, and therefore susceptible to complementmediated lysis, acquired resistance to lysis after preincubation with purified seminal and malignant cell prostasomes. The pre-incubation of PNH erythrocytes with seminal prostasomes led to what could be described as a normalization of the erythrocytes as regards their resistance to the complement attack in nearly the same way as shown by normal human erythrocytes [136]. As was indicated by flow cytometry, the normalization was the result of the transfer of prostasomal CD59 to the PNH erythrocytes. This was underlined by the blocking experiments with anti-CD59 antibodies and we concluded that the complement regulatory effect of prostasomes was indeed due to the transfer of CD59. The inhibition of CD59 by the specific antibody resulted in cells resembling the PNH cells, which concurred with data from a previous study [138].

The rabbit erythrocytes (RE) are activators of the APW of the human complement system and are lysed because their CD59 is not functional against the human complement system. We demonstrated that RE became resistant to human complement-mediated lysis by acquisition of human CD59 from seminal prostasomes in a dose dependent manner. Transfer of CD59 from malignant cell prostasomes to RE also rendered the erythrocytes less susceptible to complement lysis indicating a preserved functionality after transfer [137]. In agreement with the increased amount of CD59positive prostasomes produced by PC-3 and DU145 cells (see below), the prostasomes from these cells exhibited the most pronounced inhibitory effect. The limited antihemolytic effect of the native and LNCaP prostasomes could be related to the low proportion of CD59-positive prostasomes they produced.

\section{Transfer of Prostasomal CD59 to CD59-Deficient Cancer Cells}

Prostasomal CD59 was also transferable to PIPLCtreated malignant cells [137] indicating that prostasomes could serve as a source of CD59 for malignant cells in vivo. However, the unmanipulated DU145 and PC-3 cancer cells did not acquire additional CD59 when incubated with prostasomes. This finding suggests that all the acceptor sites on these cells were already saturated with CD59 (possibly due to the transfer from endogenous prostasomes), a conclusion that is in agreement with previous studies showing that CD59 is over-expressed on prostatic cancer cells [40]. In contrast, the untreated LNCaP cells still had unoccupied CD59-binding sites and were in this respect comparable to the PIPLC-treated DU145 and PC-3 malignant cells.

\section{Mechanism of Transfer of Prostasomal CD59 to CD59-Deficient Cells}

The transfer mechanism, i.e. the release of CD59 (which is a GPI-anchored protein [103, 104]) from prostasomes and its insertion in the membrane of acceptor cells, is not known. Väkevä et al. [139] noticed that isolated CD59 was transferred to RE in vitro by a mechanism involving high density lipoproteins (HDL) as carriers. This mechanistic approach was further elaborated by Sloand et al. [140] who showed that CD59 could be transferred to $\mathrm{PNH}$ erythrocytes in vitro using HDL preparations rich in CD59. Kooyman et al. [141] demonstrated that proteins containing (GPI) -anchor could undergo a transfer between membranes of cells in vivo. Since CD59 is a GPI -anchored protein in prostasomes, a hydrolysis is anticipated to occur before acquisition of CD59 in acceptor cell membranes. This idea is in line with our previous demonstration of release of CD59 after incubation with PIPLC and their subsequent (re-)saturation with CD59 upon incubation with prostasomes [136]. Prostasomes contain a very active phospholipase $A_{2}$ [142] but PIPLC has so far not been reported in prostasomes. A transfer also requires a close interaction between prostasomes and acceptor cells. Such an interaction has been demonstrated by different techniques to be valid for prostasomes and sperm cells [90, 143], and it is possible that similar mechanisms are working between the prostasomal and acceptor cell membranes in this study. Hence, the transfer of CD59 from prostasomal membranes to acceptor cell membranes may be the result of cooperative forces between these two membrane systems. This would be somewhat in analogy with a previous study of phosphorylation reactions concerning membrane cooperation between prostasomes and spermatozoa. Incubations of spermatozoa and prostasomes together resulted in a 10 -fold increase in total protein phosphorylation compared to the level of phosphorylation achieved when either component was incubated alone [84].

\section{E. Overexpression of CD59 by Malignant Cell Prosta- somes and Its Impact on Prostate Cancer Protection}

In our laboratory we found that prostasomes (including seminal prostasomes) derived from cells of malignant and non-malignant origin showed different expressions of CD59 
and different abilities of complement regulation [137]. Although all types of prostasomes share the property of being able of inhibiting the complement system [136, 137], this property was exaggerated in prostasomes of malignant cells.

Flow cytometric analysis of the CD59 content on the different types of prostasomes suggested that the expression of prostasomal CD59 is increased when the glandular epithelial cells of the prostate turn malignant. Both PC-3 and DU145 cells produced abundant amounts of CD59-positive prostasomes; DU145-derived prostasomes showed a higher mean intensity while PC-3 produced a subpopulation with the highest expression of CD59. In contrast, LNCaP produced prostasomes with a much lower mean CD59 intensity. These results closely resemble those obtained by Jarvis $e t a l$. [40], who using FACS on intact cells detected high levels of CD59 on PC-3 followed by DU145, and with much lower expression on LNCaP. On the whole, the malignant cell lines produced proportionally more CD59-positive prostasomes than did non-malignant cells, and the prostasomes produced by one of the malignant cell lines also expressed a much higher concentration of CD59 than did the others.

\section{F. Overexpression of Protein Kinases by Malignant Cell Prostasomes and Prostasomal ATPase Activity}

Our findings [144] demonstrated that all types of prostasomes express protein kinases (A, C) and casein kinase (CK). All prostasomes of malignant origin had significantly higher PK activity compared to seminal ones. It is particularly intriguing that $\mathrm{LNCaP}$ prostasomes which were associated with the highest PKA activity were devoid of ATPase activity, suggesting that prostasomes with these properties would be capable of a substantial phosphorylation of available biomolecules, if trapped in a secluded milieu. The low ecto-ATPase activity on prostasomes of malignant cell origin concurs with a previous observation on ecto-ATPase activity on malignant human glioma cells which was low in comparison with normal glia cells [145]. Some previous works have speculated about the source of recruitment of ATP for such phosphorylation, which may be due to direct association of nucleotides to prostasomes, such as GTP proteins [146]. The occurrence of both ADP and GDP in human prostasomes have been reported [147]. Some previous works also showed that malignant cells have higher ecto-ATP synthesizing activity $[145,148,149]$.

\section{G. Disarmament of Complement System by PKA Phos- phorylation of $\mathrm{C} 3$}

Unlike prostasomes in seminal plasma, prostasomes produced by metastatic cells of prostate cancer will be exported to the extracellular space surrounding the metastatic cells and will remain trapped within or in close vicinity to the individual cells of the tumor [11]. This will create a microenvironment where prostasomes in their extracellular location protect the prostatic malignant cells against innate immune and complement attack and thereby promote their metastasizing ability.

This indicates that the protein kinases, depending on their physiological substrate, may play a possible role in tumor pathogenesis. Paas and Fishelson [30] have described tyrosine and serine/threonine ecto-protein kinases on intact cells, e.g. monoblastoid cell line U937, and on microparticles de- rived from these cells, which among several other proteins phosphorylate $\mathrm{C} 9$ and to some extent $\mathrm{C} 3$. In a previous work by Ekdahl and Nilsson [31], it was demonstrated that C3 synthesized by monoblastoid cell line U937 was phosphorylated by CKII.

Phosphorylation is one of the mechanisms by which the modification of $\mathrm{C} 3$-function occurs. Phosphorylation of complement component $\mathrm{C} 3$ by PKA has previously been demonstrated to make it inaccessible to physiological activation [150]. The observation that $\mathrm{C} 3$ is phosphorylated by malignant prostasomal PKA [144] gives strong support to the idea that these prostasomes may indeed have the capability to disarm complement activation by regulatory phosphorylation therewith achieving an advantage of survival to the malignant cell that secreted the prostasomes.

\section{H. Procoagulant Effect of Prostasomes and Overexpres- sion of Tissue Factor (TF) by Malignant Cell Prosta- somes}

TF the main activator of the extrinsic pathway of coagulation is present in huge amounts in prostasomes [108]. We identified TF as the dominating endogenous substrate of prostasomal PKA on both malignant cell-derived and seminal prostasomes [151]. TF, which we showed to be overexpressed by malignant cell prostasomes, is known of playing additional biological roles, including the promotion of tumor angiogenesis [111, 152], cell adhesion [153], cell migration [154] and tumor cell invasion [155]. Furthermore, it binds to plasminogen with high affinity [156] an effector which may play a role in the enhancement of tumor growth and metastasis $[157,158]$. Suppression of fibrinolysis is important for metastatic prostate cancer cells. In addition to the overexpression of TF [151], this work pointed to another mechanism by which this suppression of fibrinolysis may be achieved, namely by prostasome-mediated extracellular phosphorylation of key proteins within the coagulation and fibrinolytic systems. Phosphorylation of fibrinogen has previously been shown to greatly enhance the resistance of the formed fibrin network to plasmin degradation [159]. Phosphorylation of vitronectin decreases binding of PAI-1 (plasminogen activator inhibitor-1) and plasminogen leading to suppression of fibrinolysis [160]. Previous studies have speculated about the TF phosphorylation site (the 21 amino acid cytoplasmatic region), and its involvement in the signal transduction of TF [126]. However, PKA-mediated phosphorylation in the extracellular domain of TF has not been reported previously and its impact(s) on TF function remains to be clarified. The clotting ability of prostasomes, seemingly in a dose-dependent fashion, may be related to the extent of their expression of TF. This finding is contradictory to another study revealing no difference in the plasma level of soluble TF detected in either prostate cancer patients or controls [161]. It is anticipated that prostasomes are released into the blood circulation at some point during the development of prostate cancer. Therefore, the TF activity registered in whole blood of prostate cancer patients might be prostasome-derived. On the other hand, it is not a matter of course that these prostasomes appear as free organelles in blood plasma, since they occur associated to leukocytes as indicated previously [162], which concurs with our findings in addition to their association to erythrocytes. This study suggests a major role for prostasomes in thrombotic events that 


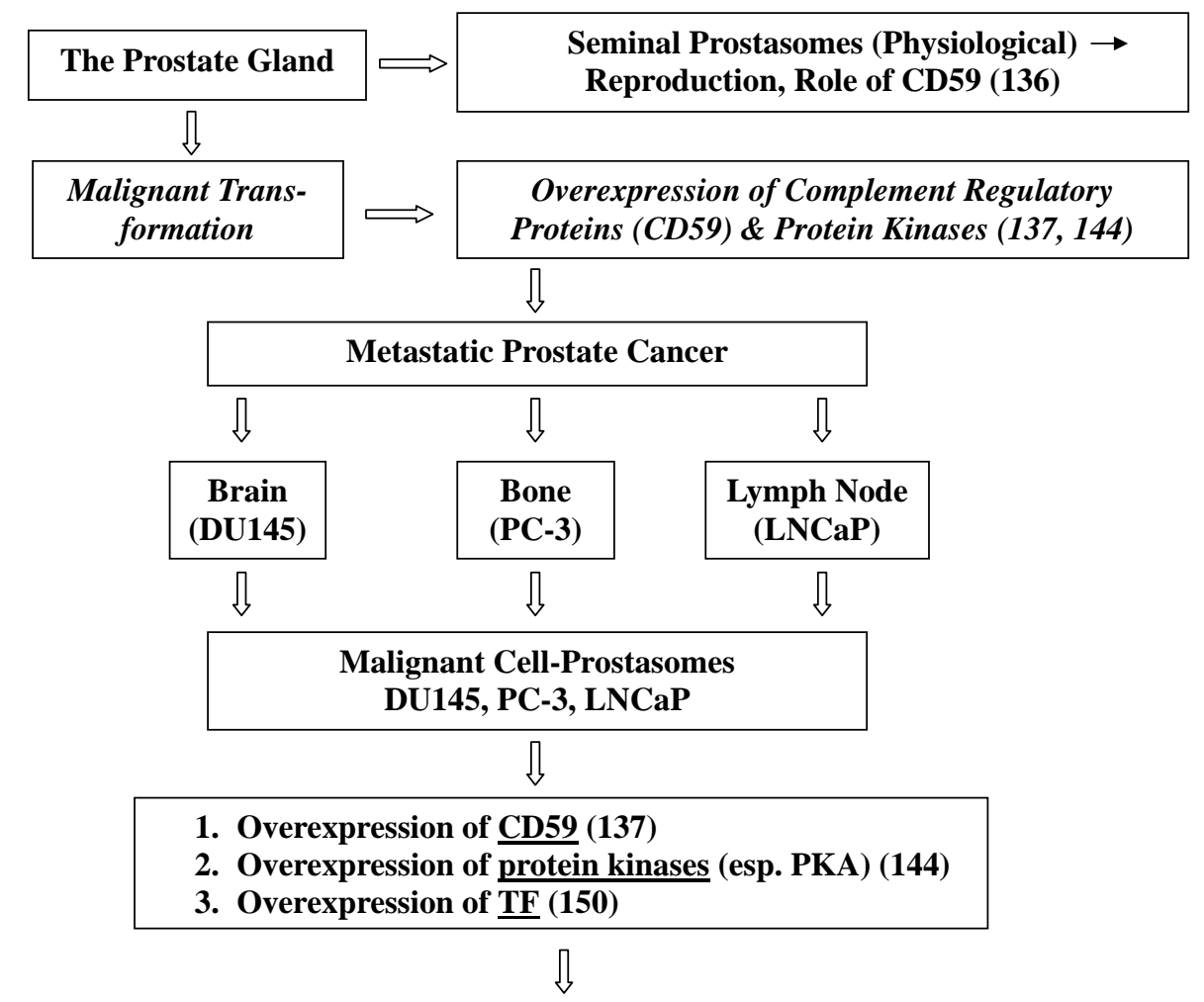

1. Protection against complement attack

2. Phosphorylation of $\underline{\mathrm{C} 3} \rightarrow$ disarmament of complement system

3. Phosphorylation of fibrinogen $\rightarrow$ impaired fibrinolysis

4. Phosphorylation of vitronectin $\rightarrow \uparrow$ angiogenesis

5. Phosphorylation of E-cadherin $\rightarrow$ cancer cell aggregation

6. Phosphorylation of $\underline{\mathrm{TF}} \rightarrow$ coagulation, angiogenesis \& cell aggregation

$\sqrt{1}$

1. $\uparrow$ cancer cell ability to survive

2. $\uparrow$ cancer cell ability to invade and destroy neighboring healthy tissues

3. $\uparrow$ cancer cell ability to further metastasize

4. $\uparrow$ incidence of clotting formation and thrombotic events (e.g. DIC)

5. Difficult treatment of DIC due to impaired fibrinolytic system

PKs: Protein Kinases (Prostasomal), DIC: Disseminated Intravascular Coagulation, TF: Tissue Factor, PKA: Protein Kinase A

Schematic representation of results, discussion and conclusions.

may occur in advanced prostate cancer favoring prostate cancer growth and development.

I. Phosphorylation of Fibrinogen, Vitronectin and the Impact on Tumor Growth, Angiogenesis and Fibrinolysis

The observation that fibrinogen and vitronectin were phosphorylated by all three prostasomal kinases (PKA, PKC and $\mathrm{CK}$ ) is equally important since fibrinogen has been implicated to play a role in tumor angiogenesis and migration of tumor cells, e.g. breast and bladder cancer [163, 164], and since it has been reported earlier that several of its functions are affected by phosphorylation with different protein kinases [165]. Vitronectin stabilizes the inhibitory form of PAI-1 that modulates fibrinolysis. It also promotes cell adhesion [166] and inhibits the lytic activity of complement
[167]. It may have a possible role in malignancy, as it is expressed at high levels in tumors [168]. Previous work showed that PKA can phosphorylate vitronectin at serine 378 , herewith affecting its conformation $[169,170]$. By this phosphorylation, vitronectin was converted from an antifibrinolytic agent that prevents the occurrence of undesired fibrinolysis into a profibrinolytic form that initiates the solubilisation of blood clots [160]. Vitronectin can also be phosphorylated by $\mathrm{PKC}$ at serine 362 which attenuates its cleavage by plasmin, thus regulating plasminogen activation [160, $170,171]$. A recent work has shown that vitronectin can be phosphorylated by CKII at threonine 50 and 57 leading to promotion of cell adhesion and spreading [170-172]. We demonstrate here that vitronectin is an ample substrate especially for prostasomes derived from malignant cells, for 
prostasomal protein kinase-catalyzed phosphorylation reactions that may influence the antifibrinolytic-fibrinolytic equilibrium in prostate cancer.

\section{J. Phosphorylation of E-cadherin and The Effect on Cell Aggregation}

The cadherin family of transmembrane glycoproteins plays an important role in cell-to-cell adhesion and cadherin dysregulation is strongly associated with prostate cancer progression [173-175]. E-cadherin was found to be downregulated in primary adenocarcinoma of the prostate with concomitant up-regulation of $\delta$-catenin [176]. Experimental disruption of E-cadherin function stimulated migration and invasion of DU145-E and other E-cadherin-positive prostate cancer cell lines [177]. A previous study has shown that phosphorylation of E-cadherin by PKD1 (PKCmu) was associated with increased cellular aggregation and decreased cellular motility in prostate cancer [178]. In our unpublished data we found that E-cadherin was phosphorylated by prostasomal PKA and we concluded that this phosphorylation of E-cadherin may be a mechanism used by metastatic cell to aggregate and achieve cell to cell adhesion.

\section{CONCLUDING REMARKS}

The above discussion and analysis of data on prostasomes (summarized in the sketch below) give a clear picture on the existence of inter-reacting and networking system that is triggered, augmented and used by cancer cells to survive the counterattack of the host biological defense system. It is also used to modify the micro-environment surrounding the tumor which enables the tumor to invade the neighboring tissues and later to metastasize to new sites where it can inflict its detrimental effect.

The understanding of the protective mechanisms utilized by the metastatic prostate cancer cells in order to avoid attack by complement and other parts of the innate immune system will help to identify suitable targets for pharmaceutical intervention. Possible targets may include GPI-anchored prostasomal proteins and specific prostasomal protein kinases present in high concentrations within close vicinity of metastatic prostate cancer cells. If the over-expression of complement regulatory proteins and these prostasomal protein kinases could be controlled or counteracted it could also be used to potentiate other types of immunotherapy.

Also, better understanding of mechanisms involving the coagulation events and the occurrence of DIC (disseminated intravascular coagulation) seen in some terminal prostate cancer patients may provide better chance for prevention and/or control of these serious clinical complications. The altered production and modified chemical properties of malignant-cell prostasomes manifesting as overexpression of some important mediators that affect the immune and coagulation blood cascade system present strong evidence that prostasomes play a pivotal role in the pathogenesis and in determining the prognosis of the prostate cancer.

\section{ACKNOWLEDGEMENTS}

We thank Dr. Lena Carlsson for valuable help in the purification of prostasomes. This work was supported by Lion`s Cancer Fund, Uppsala, Sweden, by grant-5647 from the
Swedish Medical Research Council and by faculty grants from the University of Kalmar.

\section{REFERENCES}

[1] Jemal A, Siegel R, Ward E, Hao Y, Xu J, Thun MJ. Cancer statistics, 2009. CA Cancer J Clin 2009; 59(4): 225-49.

[2] Partin AW, Carter HB, Chan DW, et al. Prostate specific antigen in the staging of localized prostate cancer: influence of tumor differentiation, tumor volume and benign hyperplasia. J Urol 1990; 143(4): 747-52.

[3] Shoa YH, Demissie K, Shih W, et al. Contemporary risk profile of prostate cancer in the United States. J Natl Cancer Inst 2009; 101(18): 1280-3.

[4] Cook LS, Goldoft M, Schwartz SM, Weiss NS. Incidence of adenocarcinoma of the prostate in Asian immigrants to the United States and their descendants. J Urol 1999; 161(1): 152-5.

[5] Shimizu H, Ross RK, Bernstein L, Yatani R, Henderson BE, Mack TM. Cancers of the prostate and breast among Japanese and white immigrants in Los Angeles County. Br J Cancer 1991; 63(3): 9636.

[6] Kyprianou N, Isaacs JT. Activation of programmed cell death in the rat ventral prostate after castration. Endocrinology 1988; 122(2): 522-62.

[7] Egle N, Altwein JE. Postpuberal castration and prostatic carcinoma. Urology 1975; 6(4): 471-3.

[8] Ormsby AH, Haskell R, Jones D, Goldblum JR. Primary seminal vesicle carcinoma: an immunohistochemical analysis of four cases. Mod Pathol 2000; 13(1): 46-51.

[9] Ronquist G, Brody I. The prostasome: its secretion and function in man. Biochim Biophys Acta 1985; 822(2): 203-18.

[10] Floryk D, Tollaksen SL, Giometti CS, Huberman E. Differentiation of human prostate cancer PC-3 cells induced by inhibitors of inosine 5'-monophosphate dehydrogenase. Cancer Res 2004; 64(24): 9049-56.

[11] Sahlen G, Ahlander A, Frost A, Ronquist G, Norlen BJ, Nilsson BO. Prostasomes are secreted from poorly differentiated cells of prostate cancer metastases. Prostate 2004; 61(3): 291-7.

[12] Ronquist G, Nilsson BO. The Janus-faced nature of prostasomes: their pluripotency favours the normal reproductive process and malignant prostate growth. Prostate Cancer Prostatic Dis 2004; 7(1): 21-31.

[13] Edelman AM, Blumenthal DK, Krebs EG. Protein serine/threonine kinases. Annu Rev Biochem 1987; 56: 567-613.

[14] Ahmed K. Significance of the casein kinase system in cell growth and proliferation with emphasis on studies of the androgenic regulation of the prostate. Cell Mol Biol Res 1994; 40(1): 1-11.

[15] Wilson MJ. Protein kinases and protein phosphorylation in prostasomes. In: Ronquist G, Nilsson BO, Eds. Prostasomes. Volume 81, Wenner-Gren International Series. London: Portland Press 2002; pp. 154-63.

[16] Podack ER, Kolb WP, Muller-Eberhard HJ. The C5b-9 complex: subunit composition of the classical and alternative pathwaygenerated complex. J Immunol 1976; 116(5): 1431-4.

[17] Dave SJ, Sodetz JM. Regulation of the membrane attack complex of complement. Evidence that C8 gamma is not the target of homologous restriction factors. J Immunol 1990; 144(8): 308790.

[18] Nakashima S, Qian Z, Rahimi S, Wasowska BA, Baldwin WMr. Membrane attack complex contributes to destruction of vascular integrity in acute lung allograft rejection. J Immunol 2002; 169(8): 4620-7.

[19] Hetland G, Johnson E, Eskeland T. Formation of the membrane attack complex of complement (MAC) on erythrocytes from monocyte-produced terminal complement components. Scand J Immunol 1987; 25(6): 571-7.

[20] Albrecht EA, Ward PA. Complement-induced impairment of the innate immune system during sepsis. Curr Allergy Asthma Rep 2004; 4(5): 359-64.

[21] Leslie RG, Nielsen $\mathrm{CH}$. The classical and alternative pathways of complement activation play distinct roles in spontaneous $\mathrm{C} 3$ fragment deposition and membrane attack complex (MAC) formation on human B lymphocytes. Immunology 2004; 111(1): 86-90.

[22] Niculescu F, Rus H. Mechanisms of signal transduction activated by sublytic assembly of terminal complement complexes on nucleated cells. Immunol Res 2001; 24(2): 191-9. 
[23] Bohana-Kashtan O, Ziporen L, Donin N, Kraus S, Fishelson Z. Cell signals transduced by complement. Mol Immunol 2004; 41(67): 583-97.

[24] Rus HG, Niculescu FI, Shin ML. Role of the C5b-9 complement complex in cell cycle and apoptosis. Immunol Rev 2001; 180: 4955

[25] Spycher MO, Nydegger UE. Participation of the blood platelet in immune reactions due to platelet-complement interaction. Infusionsther Transfusionsmed 1995; 22(1): 36-43.

[26] Sugita Y, Nakano Y, Tomita M. Isolation from human erythrocytes of a new membrane protein which inhibits the formation of complement transmembrane channels. J Biochem (Tokyo) 1988; 104(4): 633-7.

[27] Meri S, Morgan BP, Davies A, Daniels RH, Olavesen MG, Waldmann H, Lachmann PJ. Human protectin (CD59), an 18,00020,000 MW complement lysis restricting factor, inhibits C5b-8 catalysed insertion of C9 into lipid bilayers. Immunology 1990; 71(1): 1-9.

[28] Holguin MH, Fredrick LR, Bernshaw NJ, Wilcox LA, Parker CJ. Isolation and characterization of a membrane protein from normal human erythrocytes that inhibits reactive lysis of the erythrocytes of paroxysmal nocturnal hemoglobinuria. J Clin Invest 1989; 84(1): 7-17.

[29] Okada N, Harada R, Taguchi R, Okada H. Complete deficiency of $20 \mathrm{KDa}$ homologous restriction factor (HRF20) and restoration with purified HRF20. Biochem Biophys Res Commun 1989; 164(1): 468-73.

[30] Paas Y, Fishelson Z. Shedding of tyrosine and serine/threonine ecto-protein kinases from human leukemic cells. Arch Biochem Biophys 1995; 316(2): 780-8.

[31] Ekdahl KN, Nilsson B. Phosphorylation of complement component C3 after synthesis in U937 cells by a putative protein kinase, casein kinase 2, which is regulated by CD11b: evidence that membranebound proteases preferentially cleave phosphorylated C3. Biochem J 1997; 328 (Pt 2): 625-33.

[32] Yamakawa M, Yamada K, Tsuge T, et al. Protection of thyroid cancer cells by complement-regulatory factors. Cancer 1994; 73(11): 2808-17.

[33] Pangburn MK. Activation of complement via the alternative pathway. Fed Proc 1983; 42(1): 139-43.

[34] Hakulinen J, Meri S. Expression and function of the complement membrane attack complex inhibitor protectin (CD59) on human breast cancer cells. Lab Invest 1994; 71(6): 820-7.

[35] Donin N, Jurianz K, Ziporen L, Schultz S, Kirschfink M, Fishelson Z. Complement resistance of human carcinoma cells depends on membrane regulatory proteins, protein kinases and sialic acid. Clin Exp Immunol 2003; 131(2): 254-63.

[36] Jurianz K, Maslak S, Garcia-Schuler H, Fishelson Z, Kirschfink M. Neutralization of complement regulatory proteins augments lysis of breast carcinoma cells targeted with rhumAb anti-HER2. Immunopharmacology 1999; 42(1-3): 209-18.

[37] Inoue T, Yamakawa M, Takahashi T. Expression of complement regulating factors in gastric cancer cells. Mol Pathol 2002; 55(3): 193-9.

[38] Gorter A, Meri S. Immune evasion of tumor cells using membranebound complement regulatory proteins. Immunol Today 1999; 20(12): 576-82.

[39] Bjorge L, Hakulinen J, Wahlstrom T, Matre R, Meri S. Complement-regulatory proteins in ovarian malignancies. Int $\mathrm{J}$ Cancer 1997; 70(1): 14-25.

[40] Jarvis GA, Li J, Hakulinen J, et al. Expression and function of the complement membrane attack complex inhibitor protectin (CD59) in human prostate cancer. Int J Cancer 1997; 71(6): 104955 .

[41] Hofman P, Hsi BL, Manie S, Fenichel P, Thyss A, Rossi B. High expression of the antigen recognized by the monoclonal antibody GB24 on human breast carcinomas: a preventive mechanism of malignant tumor cells against complement attack? Breast Cancer Res Treat 1994; 32(2): 213-9.

[42] Koretz K, Bruderlein S, Henne C, Moller P. Decay-accelerating factor (DAF, CD55) in normal colorectal mucosa, adenomas and carcinomas. Br J Cancer 1992; 66(5): 810-4.

[43] Rosse WF. Paroxysmal nocturnal hemoglobinuria as a molecular disease. Medicine (Baltimore) 1997; 76(2): 63-93.

[44] Gazouli M, Kokotas S, Zoumpourlis V, et al. The complement inhibitor CD59 and the lymphocyte function-associated antigen-3
(LFA-3, CD58) genes possess functional binding sites for the p53 tumor suppressor protein. Anticancer Res 2002; 22(6C): 4237-41.

[45] Fair WR, Cordonnier JJ. The $\mathrm{pH}$ of prostatic fluid: a reappraisal and therapeutic implications. J Urol 1978; 120(6): 695-8.

[46] Zaichick VY, Sviridova TV, Zaichick SV. Zinc in the human prostate gland: normal, hyperplastic and cancerous. Int Urol Nephrol 1997; 29(5): 565-74.

[47] Dixon SC, Kruger EA, Bauer KS, Figg WD. Thalidomide upregulates prostate-specific antigen secretion from $\mathrm{LNCaP}$ cells. Cancer Chemother Pharmacol 1999; 43(Suppl): S78-84.

[48] Neal DEJ, Clejan S, Sarma D, Moon TD. Prostate specific antigen and prostatitis. I. Effect of prostatitis on serum PSA in the human and nonhuman primate. Prostate 1992; 20(2): 105-11.

[49] Lindholmer C, Carlstrom A, Eliasson R. Occurrence and origin of proteins in human seminal plasma with special reference to albumin. Andrologia 1974; 6(2): 181-96.

[50] Chung LW, Davies R. Prostate epithelial differentiation is dictated by its surrounding stroma. Mol Biol Rep 1996; 23(1): 13-9.

[51] Lee C. Role of androgen in prostate growth and regression: stromal-epithelial interaction. Prostate Suppl 1996; 6: 52-6.

[52] Sahlen GE, Egevad L, Ahlander A, Norlen BJ, Ronquist G, Nilsson BO. Ultrastructure of the secretion of prostasomes from benign and malignant epithelial cells in the prostate. Prostate 2002; 53(3): 1929.

[53] Ronquist G, Hedstrom M. Restoration of detergent-inactivated adenosine triphosphatase activity of human prostatic fluid with concanavalin A. Biochim Biophys Acta 1977; 483(2): 483-6.

[54] Ronquist G, Brody I, Gottfries A, Stegmayr B. An Mg2+ and $\mathrm{Ca} 2+$-stimulated adenosine triphosphatase in human prostatic fluid: part I. Andrologia 1978; 10(4): 261-72.

[55] Ronquist G, Brody I, Gottfries A, Stegmayr B. An Mg2+ and $\mathrm{Ca} 2+$-stimulated adenosine triphosphatase in human prostatic fluid-part II. Andrologia 1978; 10(6): 427-33.

[56] Pan BT, Teng K, Wu C, Adam M, Johnstone RM. Electron microscopic evidence for externalization of the transferrin receptor in vesicular form in sheep reticulocytes. J Cell Biol 1985; 101(3): 942-8.

[57] Johnstone RM, Adam M, Hammond JR, Orr L, Turbide C. Vesicle formation during reticulocyte maturation. Association of plasma membrane activities with released vesicles (exosomes). J Biol Chem 1987; 262(19): 9412-20.

[58] Johnstone RM. Exosomes biological significance: A concise review. Blood Cells Mol Dis 2006; 36(2): 315-21

[59] Stoorvogel W, Kleijmeer MJ, Geuze HJ, Raposo G. The biogenesis and functions of exosomes. Traffic 2002; 3(5): 321-30.

[60] Arvidson G, Ronquist G, Wikander G, Ojteg AC. Human prostasome membranes exhibit very high cholesterol/phospholipid ratios yielding high molecular ordering. Biochim Biophys Acta 1989; 984(2): 167-73.

[61] Arienti G, Carlini E, Polci A, Cosmi EV, Palmerini CA. Fatty acid pattern of human prostasome lipid. Arch Biochem Biophys 1998; 358(2): 391-5.

[62] Poliakov A, Spilman M, Dokland T, Amling CL, Mobley JA. Structural heterogeneity and protein composition of exosome-like vesicles (prostasomes) in human semen. Prostate 2009; 69(2): 15967

[63] Trajkovic K, Hsu C, Chiantia S, et al. Ceramide triggers budding of exosome vesicles into multivesicular endosomes. Science 2008; 319(5867): 1244-7.

[64] Simons M, Raposo G. Exosomes--vesicular carriers for intercellular communication. Curr Opin Cell Biol 2009; 21(4): 575-81.

[65] Kaighn ME, Narayan KS, Ohnuki Y, Lechner JF, Jones LW. Establishment and characterization of a human prostatic carcinoma cell line (PC-3). Invest Urol 1979; 17(1): 16-23.

[66] Lu Q, Zhang J, Allison R, et al. Identification of extracellular deltacatenin accumulation for prostate cancer detection. Prostate 2004 69(4): 411-8

[67] Llorente A, de Marco MC, Alonso MA. Caveolin-1 and MAL are located on prostasomes secreted by the prostate cancer PC-3 cell line. J Cell Sci 2004; 117(Pt 22): 5343-51.

[68] Llorente A, van Deurs B, Sandvig K. Cholesterol regulates prostasome release from secretory lysosomes in $\mathrm{PC}-3$ human prostate cancer cells. Eur J Cell Biol 2007; 86(7): 405-15.

[69] Carlsson L, Nilsson O, Larsson A, Stridsberg M, Sahlen G, Ronquist $\mathrm{G}$. Characteristics of human prostasomes isolated from three different sources. Prostate 2003; 54(4): 322-30. 
[70] Mack SR, Everingham J, Zaneveld LJ. Isolation and partial characterization of the plasma membrane from human spermatozoa. J Exp Zool 1986; 240(1): 127-36.

[71] Ronquist G. Effect of modulators on prostasome membrane-bound ATPase in human seminal plasma. Eur J Clin Invest 1987; 17(3): 231-6.

[72] Ronquist G, Frithz G, Jansson A. Prostasome membrane associated enzyme activities and semen parameters in men attending an infertility clinic. Urol Int 1988; 43(3): 133-8.

[73] Verhoeven G, Steeno O. Evidence for the prostatic origin of gamma-glutamyltranspeptidase activity in human semen. Andrologia 1979; 11(2): 163-7.

[74] Lilja H, Weiber H. gamma-Glutamyltransferase bound to prostatic subcellular organelles and in free form in human seminal plasma. Scand J Clin Lab Invest 1983; 43(4): 307-12.

[75] Oliw EH, Fabiani R, Johansson L, Ronquist G. Arachidonic acid 15-lipoxygenase and traces of E prostaglandins in purified human prostasomes. J Reprod Fertil 1993; 99(1): 195-9.

[76] Lax Y, Grossman S, Rubinstein S, Magid N, Breitbart H. Role of lipoxygenase in the mechanism of acrosome reaction in mammalian spermatozoa. Biochim Biophys Acta 1990; 12(1043(1)): 128 .

[77] Renneberg H, Albrecht M, Kurek R, Krause E, Lottspeich F, Aumuller G, Wilhelm B. Identification and characterization of neutral endopeptidase (EC 3. 4. 24. 11) from human prostasomes--localization in prostatic tissue and cell lines. Prostate 2001; 46(3): 17383.

[78] Fabiani R, Ronquist G. Characteristics of membrane-bound 5'nucleotidase on human prostasomes. Clin Chim Acta 1993; 216(12): $175-82$.

[79] Vanhoof G, De Meester I, van Sande M, Scharpe S, Yaron A. Distribution of proline-specific aminopeptidases in human tissues and body fluids. Eur J Clin Chem Clin Biochem 1992; 30(6): 3338.

[80] Fleischer B. CD26: a surface protease involved in T-cell activation. Immunol Today 1994; 15(4): 180-4.

[81] Yaron A, Naider F. Proline-dependent structural and biological properties of peptides and proteins. Crit Rev Biochem Mol Biol 1993; 28(1): 31-81.

[82] Vanhoof G, Goossens F, De Meester I, Hendriks D, Scharpe S. Proline motifs in peptides and their biological processing. FASEB J 1995; 9(9): 736-44.

[83] Laurell CB, Weiber H, Ohlsson K, Rannevik G. A zinc-dependent peptidase in prostatic organelles present in seminal plasma. Clin Chim Acta 1982; 126(2): 161-70.

[84] Stegmayr B, Brody I, Ronquist G. A biochemical and ultrastructural study on the endogenous protein kinase activity of secretory granule membranes of prostatic origin in human seminal plasma. $\mathbf{J}$ Ultrastruct Res 1982; 78(2): 206-14

[85] Majumder GC, Haldar S, Dey CS, Barua M, Roy N. Occurrence of several ecto-proteins on goat spermatozoal surface that may regulate flagellar motility. Indian J Biochem Biophys 1988; 25(1-2): 215-8.

[86] Huacuja L, Delgado NM, Merchant H, Pancardo RM, Rosado A. Cyclic AMP induced incorporation of $3 \mathrm{Pi}$ into human spermatozoa membrane components. Biol Reprod 1977; 17(1): 89-96.

[87] Lee MY, Iverson RM. An adenosine 3':5' monophosphate dependent protein kinase from sea urchin spermatozoa. Biochim Biophys Acta 1976; 429(1): 123-36.

[88] Hoskins DD, Casillas ER, Stephens DT. Cyclic AMP-dependent protein kinases of bovine epididymal spermatozoa. Biochem Biophys Res Commun 1972; 48(6): 1131-8.

[89] Ek P, Malm J, Lilja H, Carlsson L, Ronquist G. Exogenous protein kinases $\mathrm{A}$ and $\mathrm{C}$, but not endogenous prostasome-associated protein kinase, phosphorylate semenogelins I and II from human semen. J Androl 2002; 23(6): 806-14.

[90] Ronquist G, Nilsson BO, Hjerten S. Interaction between prostasomes and spermatozoa from human semen. Arch Androl 1990; 24(2): 147-57.

[91] Carlini E, Palmerini CA, Cosmi EV, Arienti G. Fusion of sperm with prostasomes: effects on membrane fluidity. Arch Biochem Biophys 1997; 343(1): 6-12.

[92] Minelli A, Allegrucci C, Mezzasoma I, Ronquist G, Lluis C, Franco R. CD26 and adenosine deaminase interaction: its role in the fusion between horse membrane vesicles and spermatozoa. Biol Reprod 1999; 61(3): 802-8.
[93] Arienti G, Carlini E, Verdacchi R, Palmerini CA. Transfer of aminopeptidase activity from prostasomes to sperm. Biochim Biophys Acta 1997; 1336(2): 269-74.

[94] Arienti G, Polci A, Carlini E, Palmerini CA. Transfer of CD26/dipeptidyl peptidase IV (E.C. 3.5.4.4) from prostasomes to sperm. FEBS Lett 1997; 410(2-3): 343-6.

[95] Fabiani R, Johansson L, Lundkvist O, Ulmsten U, Ronquist G. Promotive effect by prostasomes on normal human spermatozoa exhibiting no forward motility due to buffer washings. Eur J Obstet Gynecol Reprod Biol 1994; 57(3): 181-8.

[96] Fabiani R, Johansson L, Lundkvist Ö, Ronquist G. Enhanced recruitment of motile spermatozoa by prostasome inclusion in swimup medium. Hum Reprod 1994; 9(8): 1485-9.

[97] Stegmayr B, Ronquist G. Promotive effect on human sperm progressive motility by prostasomes. Urol Res 1982; 10(5): 253-7.

[98] Coddington CC, Franken DR, Burkman LJ, Oosthuizen WT, Kruger T, Hodgen GD. Functional aspects of human sperm binding to the zona pellucida using the hemizona assay. J Androl 1991; 12(1): 1-8.

[99] Carlsson L, Pahlson C, Bergquist M, Ronquist G, Stridsberg M. Antibacterial activity of human prostasomes. Prostate 2000; 44(4): 279-86.

[100] Kitamura M, Namiki M, Matsumiya K, et al. Membrane cofactor protein (CD46) in seminal plasma is a prostasome-bound form with complement regulatory activity and measles virus neutralizing activity. Immunology 1995; 84(4): 626-32.

[101] Skibinski G, Kelly RW, Harkiss D, James K. Immunosuppression by human seminal plasma--extracellular organelles (prostasomes) modulate activity of phagocytic cells. Am J Reprod Immunol 1992; 28(2): 97-103.

[102] Saez F, Motta C, Boucher D, Grizard G. Antioxidant capacity of prostasomes in human semen. Mol Hum Reprod 1998; 4(7): 66772

[103] Rooney IA, Heuser JE, Atkinson JP. GPI-anchored complement regulatory proteins in seminal plasma. An analysis of their physical condition and the mechanisms of their binding to exogenous cells. J Clin Invest 1996; 97(7): 1675-86.

[104] Rooney IA, Atkinson JP, Krul ES, et al. Physiologic relevance of the membrane attack complex inhibitory protein CD59 in human seminal plasma: CD59 is present on extracellular organelles (prostasomes), binds cell membranes, and inhibits complementmediated lysis. J Exp Med 1993; 177(5): 1409-20.

[105] Kelly RW, Holland P, Skibinski G, et al. Extracellular organelles (prostasomes) are immunosuppressive components of human semen. Clin Exp Immunol 1991; 86(3): 550-6.

[106] Kelly RW. Immunosuppressive mechanisms in semen: implications for contraception. Hum Reprod 1995; 10(7): 1686-93

[107] Huggins C, Neal W. Coagualtion and liquifaction of semen: Proteolytic enzymes and citrate in prostate fluid. J Exp Med 1942; 76: 527-41.

[108] Fernandez JA, Heeb MJ, Radtke KP, Griffin JH. Potent blood coagulant activity of human semen due to prostasome-bound tissue factor. Biol Reprod 1997; 56(3): 757-63.

[109] Fareed J, Callas DD, Hoppensteadt D, Bermes EJ. Tissue factor antigen levels in various biological fluids. Blood Coagul Fibrinolysis 1995; 6(Suppl 1): S32-6.

[110] Carson SD, De Jonge CJ. Activation of coagulation factor X in human semen. J Androl 1998; 19(3): 289-94.

[111] Zhang Y, Deng Y, Luther T, et al. Tissue factor controls the balance of angiogenic and antiangiogenic properties of tumor cells in mice. J Clin Invest 1994; 94(3): 1320-7.

[112] Folkman J. Tumor angiogenesis and tissue factor. Nat Med 1996; 2(2): 167-8.

[113] Nakagawa K, Zhang Y, Tsuji H, et al. The angiogenic effect of tissue factor on tumors and wounds. Semin Thromb Hemost 1998; 24(3): 207-10

[114] Luther T, Flossel C, Mackman N, et al. Tissue factor expression during human and mouse development. Am J Pathol 1996; 149(1): 101-13.

[115] Carmeliet P, Mackman N, Moons L, et al. Role of tissue factor in embryonic blood vessel development. Nature 1996; 383(6595): 73 5.

[116] Lwaleed BA, Greenfield R, Stewart A, Birch B, Cooper AJ. Seminal clotting and fibrinolytic balance: a possible physiological role in the male reproductive system. Thromb Haemost 2004; 92(4): $752-66$. 
[117] Matsuda Y, Shimokawa K, Katayama M, et al. Blood coagulation factor X (FX) in human seminal plasma. Arch Androl 2002; 48(4): 295-300.

[118] Lwaleed BA, Greenfield R, Royle E, Birch B, Cooper AJ. Seminal Factor VIII and von Willebrand Factor: a possible role of the conventional clotting system in human semen? Int J Androl 2005; 28(1): 31-8.

[119] Dunn CL, Kelly RW, Critchley HO. Decidualization of the human endometrial stromal cell: an enigmatic transformation. Reprod Biomed Online 2003; 7(2): 151-61.

[120] Kohli M, Fink LM, Spencer HJ, Zent CS. Advanced prostate cancer activates coagulation: a controlled study of activation markers of coagulation in ambulatory patients with localized and advanced prostate cancer. Blood Coagul Fibrinolysis 2002; 13(1): $1-5$.

[121] Ohta S, Wada H, Nakazaki T, et al. Expression of tissue factor is associated with clinical features and angiogenesis in prostate cancer. Anticancer Res 2002; 22(5): 2991-6.

[122] Abdulkadir SA, Carvalhal GF, Kaleem Z, et al. Tissue factor expression and angiogenesis in human prostate carcinoma. Hum Pathol 2000; 31(4): 443-7.

[123] Hjortoe GM, Petersen LC, Albrektsen T, et al. Tissue factor-factor VIIa-specific up-regulation of IL-8 expression in MDA-MB-231 cells is mediated by PAR-2 and results in increased cell migration. Blood 2004; 103(8): 3029-37.

[124] Akashi T, Furuya Y, Ohta S, Fuse H. Tissue factor expression and prognosis in patients with metastatic prostate cancer. Urology 2003; 62(6): 1078-82

[125] Zhang S, Zhang HS, Reuter VE, Slovin SF, Scher HI, Livingston PO. Expression of potential target antigens for immunotherapy on primary and metastatic prostate cancers. Clin Cancer Res 1998; 4(2): 295-302.

[126] Mody RS, Carson SD. Tissue factor cytoplasmic domain peptide is multiply phosphorylated in vitro. Biochemistry 1997; 36(25): 786975.

[127] Bach R, Konigsberg WH, Nemerson Y. Human tissue factor contains thioester-linked palmitate and stearate on the cytoplasmic half-cystine. Biochemistry 1988; 27(12): 4227-31.

[128] Zioncheck TF, Roy S, Vehar GA. The cytoplasmic domain of tissue factor is phosphorylated by a protein kinase C-dependent mechanism. J Biol Chem 1992; 267(6): 3561-4.

[129] Hunter T. Protein kinase classification. Methods Enzymol 1991; 200: 3-37.

[130] Ahmed K, Wilson MJ. Chromatin-associated protein phosphokinases of rat ventral prostate. Characteristics and effects of androgenic status. J Biol Chem 1975; 250(6): 2370-5.

[131] Majumder GC. Characterization of a protein kinase from human seminal plasma. Biochem Biophys Res Commun 1978; 81(4): 1217-26.

[132] Wilson MJ, Steer RC, Kaye KW. Presence and characterization of two protein kinase activities in human seminal fluid. Biochim Biophys Acta 1982; 700(2): 206-12.

[133] Wilson MJ, Kaye KW. Tissue sources of protein kinase activities in human seminal fluid: studies of normal, oligozoospermic, and vasectomized men. Fertil Steril 1983; 40(1): 105-9.

[134] Steer RC, Wilson MJ, Ahmed K, Veneziale CM. Protein phosphatase activity of nuclear envelope from seminal vesicle epithelium. Cell Mol Biol 1982; 28(6): 559-64.

[135] Wilson MJ, Steer RC, Kaye KW. Protein kinase activities in human prostatic secretion: biochemical characterization and effect of prostatitis. J Lab Clin Med 1984; 103(6): 905-11.

[136] Babiker AA, Ronquist G, Nilsson UR, Nilsson B. Transfer of prostasomal CD59 to CD59-deficient red blood cells results in protection against complement-mediated hemolysis. Am J Reprod Immunol 2002; 47(3): 183-92.

[137] Babiker AA, Nilsson B, Ronquist G, Carlsson L, Ekdahl KN. Transfer of functional prostasomal CD59 of metastatic prostatic cancer cell origin protects cells against complement attack. Prostate 2005; 62(2): 105-14

[138] Yuan FF, Bryant JA, Fletcher A. Protease-modified erythrocytes: CD55 and CD59 deficient PNH-like cells. Immunol Cell Biol 1995; 73(1): 66-72.

[139] Väkevä A, Jauhiainen M, Ehnholm C, Lehto T, Meri S. Highdensity lipoproteins can act as carriers of glycophosphoinositol lipid-anchored CD59 in human plasma. Immunology 1994; 82(1): 28-33.
[140] Sloand EM, Maciejewski JP, Dunn D, et al. Correction of the PNH defect by GPI-anchored protein transfer. Blood 1998; 92(11): 4439-45.

[141] Kooyman DL, Byrne GW, McClellan S, et al. In vivo transfer of GPI-linked complement restriction factors from erythrocytes to the endothelium. Science 1995; 269(5220): 89-92.

[142] Lindahl M, Tagesson C, Ronquist G. Phospholipase A2 activity in prostasomes from human seminal plasma. Urol Int 1987; 42(5): 385-9.

[143] Wang J, Lundqvist M, Carlsson L, Nilsson O, Lundkvist O, Ronquist G. Prostasome-like granules from the PC-3 prostate cance cell line increase the motility of washed human spermatozoa and adhere to the sperm. Eur J Obstet Gynecol Reprod Biol 2001; 96(1): 88-97.

[144] Babiker AA, Nilsson B, Ronquist G, Ekdahl KN. Overexpression of ecto-protein kinases in prostasomes of metastatic cell origin. Prostate 2006; 66(7): 675-86.

[145] Ågren G, Ponten J, Ronquist G, Westermark B. Demonstration of an ATPase at the cell surface of intact normal and neoplastic human cells in culture. J Cell Physiol 1971; 78(2): 171-6.

[146] Utleg AG, Yi EC, Xie T, et al. Proteomic analysis of human prostasomes. Prostate 2003; 56(2): 150-61.

[147] Ronquist G, Frithz GG. Prostasomes in human semen contain ADP and GDP. Acta Eur Fertil 1986; 17(4): 273-6.

[148] Ågren G, Ponten J, Ronquist G, Westermark B. Formation of extracellular adenosine triphosphate by normal and neoplastic human cells in culture. J Cell Physiol 1971; 77(3): 331-6.

[149] Ågren G, Ronquist G. Formation of extracellular adenosine triphosphate by tumour cells. Acta Physiol Scand 1969; 75(1): 124 8.

[150] Forsberg PO, Martin SC, Nilsson B, Ekman P, Nilsson UR, Engstrom L. In vitro phosphorylation of human complement factor $\mathrm{C} 3$ by protein kinase $\mathrm{A}$ and protein kinase $\mathrm{C}$. Effects on the classical and alternative pathways. J Biol Chem 1990; 265(5): 29416.

[151] Babiker AA, Hamad OA, Sanchez J, Ronquist G, Nilsson B, Ekdahl KN. Prothrombotic effect of prostasomes of metastatic cell and seminal origin. Prostate 2007; 67: 378-88.

[152] Abe K, Shoji M, Chen J, et al. Regulation of vascular endothelial growth factor production and angiogenesis by the cytoplasmic tail of tissue factor. Proc Natl Acad Sci USA 1999; 96(15): 8663-8

[153] Ott I, Fischer EG, Miyagi Y, Mueller BM, Ruf W. A role for tissue factor in cell adhesion and migration mediated by interaction with actin-binding protein 280. J Cell Biol 1998; 140(5): 1241-53.

[154] Sato Y, Asada Y, Marutsuka K, Hatakeyama K, Sumiyoshi A. Tissue factor induces migration of cultured aortic smooth muscle cells. Thromb Haemost 1996; 75(3): 389-92.

[155] Bromberg ME, Konigsberg WH, Madison JF, Pawashe A, Garen A. Tissue factor promotes melanoma metastasis by a pathway independent of blood coagulation. Proc Natl Acad Sci USA 1995; 92(18): 8205-9.

[156] Gonzalez-Gronow M, Gawdi G, Pizzo SV. Tissue factor is the receptor for plasminogen type 1 on 1-LN human prostate cancer cells. Blood 2002; 99(12): 4562-7.

[157] de Vries TJ, van Muijen GN, Ruiter DJ. The plasminogen activation system in tumour invasion and metastasis. Pathol Res Pract 1996; 192(7): 718-33.

[158] Andreasen PA, Kjoller L, Christensen L, Duffy MJ. The urokinasetype plasminogen activator system in cancer metastasis: a review. Int J Cancer 1997; 72(1): 1-22

[159] Forsberg PO, Martin SC. Phosphorylation/dephosphorylation and the regulation of fibrinogen and complement factor C3. Ups J Med Sci 1991; 96(2): 75-93

[160] Schvartz I, Kreizman T, Brumfeld V, Gechtman Z, Seger D, Shaltiel S. The PKA phosphorylation of vitronectin: effect on conformation and function. Arch Biochem Biophys 2002; 397(2): 24652

[161] Caine GJ, Lip GY, Stonelake PS, Ryan P, Blann AD. Platelet activation, coagulation and angiogenesis in breast and prostate carcinoma. Thromb Haemost 2004; 92(1): 185-90.

[162] Arienti G, Carlini E, Saccardi C, Palmerini CA. Interactions between prostasomes and leukocytes. Biochim Biophys Acta 1998 1425(1): 36-40.

[163] Roche Y, Pasquier D, Rambeaud JJ, Seigneurin D, Duperray A. Fibrinogen mediates bladder cancer cell migration in an ICAM-1dependent pathway. Thromb Haemost 2003; 89(6): 1089-97. 
[164] Simpson-Haidaris PJ, Rybarczyk B. Tumors and fibrinogen. The role of fibrinogen as an extracellular matrix protein. Ann NY Acad Sci 2001; 936: 406-25.

[165] Martin SC, Forsberg PO, Eriksson SD. The effects of in vitro phosphorylation and dephosphorylation on the thrombin-induced gelation and plasmin degradation of fibrinogen. Thromb Res 1991; 61(3): 243-52

[166] Hynes RO. Integrins: versatility, modulation, and signaling in cell adhesion. Cell 1992; 69(1): 11-25.

[167] Dahlbäck B, Podack ER. Characterization of human S protein, an inhibitor of the membrane attack complex of complement. Demonstration of a free reactive thiol group. Biochemistry 1985; 24(9): 2368-74

[168] Seiffert D. Constitutive and regulated expression of vitronectin. Histol Histopathol 1997; 12(3): 787-97.

[169] Shaltiel S, Schvartz I, Korc-Grodzicki B, Kreizman T. Evidence for an extra-cellular function for protein kinase A. Mol Cell Biochem 1993; 127-128: 283-91.

[170] Schvartz I, Seger D, Shaltiel S. Vitronectin. Int J Biochem Cell Biol 1999; 31(5): 539-44.

[171] Seger D, Gechtman Z, Shaltiel S. Phosphorylation of vitronectin by casein kinase II. Identification of the sites and their promotion of cell adhesion and spreading. J Biol Chem 1998; 273(38): 24805-13.

[172] Seger D, Seger R, Shaltiel S. The CK2 phosphorylation of vitronectin. Promotion of cell adhesion via the alpha(v)beta 3- phosphatidylinositol 3-kinase pathway. J Biol Chem 2001; 276(20): 16998-7006.

[173] Yap AS. The morphogenetic role of cadherin cell adhesion molecules in human cancer: a thematic review. Cancer Invest 1998; 16(4): 252-61.

[174] Umbas R, Isaacs WB, Bringuier PP, et al. Decreased E-cadherin expression is associated with poor prognosis in patients with prostate cancer. Cancer Res 1994; 54(14): 3929-33.

[175] Bringuier PP, Umbas R, Schaafsma HE, Karthaus HF, Debruyne FM, Schalken JA. Decreased E-cadherin immunoreactivity correlates with poor survival in patients with bladder tumors. Cancer Res 1993; 53(14): 3241-5.

[176] Lu Q, Dobbs LJ, Gregory CW, et al. Increased expression of deltacatenin/neural plakophilin-related armadillo protein is associated with the down-regulation and redistribution of E-cadherin and p120ctn in human prostate cancer. Hum Pathol 2005; 36(10): 1037 48 .

[177] Chunthapong J, Seftor EA, Khalkhali-Ellis Z, et al. Dual roles of E-cadherin in prostate cancer invasion. J Cell Biochem 2004; 91(4): 649-61.

[178] Jaggi M, Rao PS, Smith DJ, et al. E-cadherin phosphorylation by protein kinase $\mathrm{D} 1 /$ protein kinase $\mathrm{C}\{\mathrm{mu}\}$ is associated with altered cellular aggregation and motility in prostate cancer. Cancer Res 2005; 65(2): 483-92. 